\title{
Immunoglobulin Levels during Follow-up of Children with Selective IgA Deficiency
}

\author{
P. C. J. DE LAAT, C. M. R. WEEMAES \& J. A. J. M. BAKKEREN \\ Department of Pediatrics, University Hospital Nijmegen, Nijmegen, The Netherlands
}

\begin{abstract}
de Laat PCJ, Weemaes CMR, Bakkeren JAJM. Immunoglobulin Levels during Follow-Up of Children with Selective IgA Deficiency. Scand J Immunol 1992;35:719-25

Longitudinal serum immunoglobulin levels were studied in 36 children with selective IgA deficiency during a median follow-up period of 5 years. Twenty-five children were 'sporadic' cases, and 11 were 'familial'. Serum and saliva IgA levels in 23 children remained below $2 \mathrm{mg} / \mathrm{l}$. Eight children with $\operatorname{IgA}$ levels above $2 \mathrm{mg} / \mathrm{l}$ showed considerable intra-individual variance in serum IgA, but remained IgA deficient. Five children at various ages developed IgA levels above $50 \mathrm{mg} / \mathrm{l}$ with detectable secretory $\mathrm{IgA}$ in saliva. In most of the children $\mathrm{IgG}$ subclass levels were found to be rather high, including at younger ages. There were no obvious differences between 'sporadic' and 'familial' cases except an association between IgD deficiency and serum IgA levels below $2 \mathrm{mg} / \mathrm{l}$, and between serum levels of $\mathrm{IgD}$ above $1 \mathrm{IU} / \mathrm{ml}$ and of $\mathrm{IgA}$ above $2 \mathrm{mg} / \mathrm{l}$, which was found to be significant in the 'sporadic' group but not in the 'familial' group.
\end{abstract}

\section{P. C. J. de Laat, Department of Pediatrics, Sophia Children's Hospital, 3038 GE Rotterdam, The Netherlands}

Selective IgA deficiency is the most frequent primary immunodeficiency [1-3]. Clinical manifestations are heterogeneous, and vary from none at all to associations with autoimmune disease, recurrent infections, and atopic disease [1-4]. Familial occurrence of selective IgA deficiency with various patterns of inheritance has been reported [4, 5], but most patients described represent sporadic cases.

Concomitant deficiencies of one or more IgG subclasses, $\mathrm{IgD}$ and/or IgE have been reported in IgA-deficient individuals [6-10]. Serum IgA levels are not constant, and even at levels below $0.5 \mathrm{mg} / \mathrm{l}$ significant fluctuations were noted [11]. Several cases of transient IgA deficiency have been found in follow-up studies [4, 12]. However, most data on serum immunoglobulin levels in patients with selective $\operatorname{IgA}$ deficiency are derived from crosssectional studies in selected populations [1, 6-10].

In this study we report longitudinal immunoglobulin levels in a group of 36 children during a median follow-up period of 5 years, subgrouping 'sporadic' and 'familial' cases.

\section{PATIENTS AND METHODS}

Patients. IgA deficiency was defined according to
Hong \& Ammann [2]: serum IgA level below $50 \mathrm{mg} / \mathrm{l}$, normal serum $\mathrm{IgG}$ and $\mathrm{IgM}$ levels, and no or at most mild abnormalities of T-cell function. Diagnosis was only made after the age of one year. Sibs and parents of 25 children had normal serum IgA levels, and these children were designated as 'sporadic.' The remaining 11 children had a sib with selective IgA deficiency and are considered as 'familial' cases. The clinical manifestations in our patients have been reported previously, and mainly consisted of mild respiratory tract infections [13].

The median age at diagnosis was 5.4 years (range 1 to 16). The median follow-up period was 5 years (range 2 to 10). Out-patient follow-up visits took place at least 2 3 times yearly, serum immunoglobulin levels were measured, and all patients were checked for development of anti-IgA antibodies. In 32 children secretory $\mathrm{IgA}$ was measured in saliva once or twice.

Methods. Serum IgG and IgM levels were measured by a single radial immunodiffusion according to Van Munster et al. [14] or by laser-nephelometry. All values were calibrated against WHO standard serum No. 67/ 97. Age- and sex-specific reference values have been determined in an earlier study [15]. IgA levels in serum and saliva (and if present the amount of class-specific anti-IgA antibodies) were measured by a titrationradioimmunoassay as described previously [16]. Saliva was collected from the parotid gland by parotid cup, in place for $15 \mathrm{~min}$ before stimulation during a 10 -min period [7]. In healthy adults $(n=13)$ the mean $\operatorname{IgA}$ level in saliva was $35 \mathrm{mg} / \mathrm{l}$ (SD 10, range $15-48 \mathrm{mg} / \mathrm{l}$ ). IgG subclass levels were measured by radial immunodiffusion with polyclonal sheep anti-human IgG subclasses antiserum (SH 161, 162, 163, 164 resp. The Central 
Laboratory of the Netherlands Red Cross Blood Transfusion Service). The values were calibrated against reference serum containing $\operatorname{IgG}_{1} 6.2 \mathrm{~g} / \mathrm{l} ; \mathrm{IgG}_{2} 2.4 \mathrm{~g} / \mathrm{l}$; $\mathrm{IgG}_{3} 0.64 \mathrm{~g} / \mathrm{l}$ and $\mathrm{IgG}_{4} 0.46 \mathrm{~g} / \mathrm{l}$ (HOO-020, The Central Laboratory of the Netherlands Red Cross Blood Transfusion Service). $\mathrm{IgG}_{1}, \mathrm{IgG}_{2}$ and $\mathrm{IgG}_{3}$ levels were compared with the age-related normal values described by Plebani et al. [17]. Values below the third percentile $\left(\mathrm{P}_{3}\right)$ were considered as an indication of deficiency of the respective IgG subclass. Due to the very broad spread in childhood, reference values for $\mathrm{IgG}_{4}$ are not available, and $\mathrm{IgG}_{4}$ deficiency is difficult to define [17]. In our study an arbitrary level of $0.046 \mathrm{~g} / \mathrm{l}$ was chosen to delineate at least very low levels, probably indicating concomitant $\mathrm{IgG}_{4}$ deficiency. Serum $\mathrm{IgD}$ levels were measured by enzyme-linked immunosorbent assay (ELISA) and serum IgE levels by radioimmunoassay. The IgD standard (Behringwerke AG, Marburg, Germany) has been calibrated against the British Research Standard No. 67/37. The IgE standards (Pharmacia AB, Uppsala, Sweden) have been calibrated against the 1st British Standard 75/502 for human serum IgE (1977) (National Institute for Biological Standards and Controls). Levels below the detection limits ( 1 and $5 \mathrm{IU} / \mathrm{ml}$, respectively) were considered as an indication for $\mathrm{IgD}$ or IgE deficiency. Serum IgE was designated as 'high' if measurements were above $+1 \mathrm{SD}$ of the reference values provided by Kjellman [18].

\section{RESULTS}

\section{Serum immunoglobulins}

IgA was detectable in very small amounts in serum of all patients except an 18-year-old girl who was the only patient with circulating classspecific anti-IgA antibodies. During the followup period IgA levels in 23 of our patients remained below $2 \mathrm{mg} / \mathrm{l}$. One of them initially had IgA levels around $50 \mathrm{mg} / 1$ while she suffered from lymphadenitis. Within 2 months IgA levels declined to below $2 \mathrm{mg} / \mathrm{l}$. Considerable fluctuations in serum $\operatorname{IgA}$ levels were found in 8 children, but all remained IgA deficient (Fig. 1). The relative elevations of serum $\operatorname{IgA}$ in these patients were not related to periods with an increased rate of infections. Associations between longitudinal serum IgA levels and longitudinal serum levels of IgG or IgM could not be established. In 5 children serum IgA levels rose above $50 \mathrm{mg} / \mathrm{l}$, but none of them attained the lower range of age-specific reference values (Fig. 2).

Longitudinal $\mathrm{IgD}$ levels were below $1 \mathrm{IU} / \mathrm{ml}$ in 15 children, and 12 of them had serum IgA levels below $2 \mathrm{mg} / \mathrm{l}$. IgD levels were above $1 \mathrm{IU} / \mathrm{ml}$ in 13 children, and 10 of them had serum IgA levels above $2 \mathrm{mg} / \mathrm{l}$. The relationship observed between longitudinal serum $\operatorname{IgA}$ and $\operatorname{IgD}$ levels was statistically significant ( $P=0.007$, Fisher test) in the 'sporadic' group but not in the 'familial' group (Table I). There were no obvious differences in clinical manifestations between 'sporadic' and 'familial' patients [13]. The rate of infections was not associated with the height of the serum IgD levels. Three patients developed undetectable $\operatorname{IgD}$ levels during follow-up. IgA levels in one of them were always below $2 \mathrm{mg} / \mathrm{l}$. The other two patients initially developed IgA levels above $50 \mathrm{mg} / \mathrm{l}$. Later on, coinciding with a drop in IgD levels to undetectable values, maturation of their IgA system seemed hampered (C.W. and D.F., Fig. 2). One of the 'familial' patients (PD, Fig. 1) demonstrated IgD deficiency during the entire follow-up period while IgA levels remained around $20 \mathrm{mg} / 1$. In 7 children with variable $\mathrm{IgA}$ levels (above $2 \mathrm{mg} / \mathrm{l}$ ) and in 3 children with serum IgA levels above $50 \mathrm{mg} / \mathrm{l}, \mathrm{IgD}$ levels were above $1 \mathrm{IU} / \mathrm{ml}$ (Table I).

$\mathrm{IgE}$ levels below $5 \mathrm{IU} / \mathrm{ml}$ were found in 10 children ( 8 'sporadic' and 2 'familial'). In 5 of the 'sporadic' patients serum IgE went below $5 \mathrm{IU} / \mathrm{ml}$ during follow-up. Eleven children (5 'sporadic' and 6 'familial') demonstrated high levels of IgE. There was no consistent association between height of serum IgE and atopic complaints. Three 'sporadic' patients had atopic complaints despite $\mathrm{IgE}$ levels below $5 \mathrm{IU} / \mathrm{ml}$, and in two of them RAST tests for specific IgE (Phadiatop, Pharmacia Diagnostics, Woerden, The Netherlands) were positive. Six out of the 11 children with high IgE levels showed positive RAST tests for specific $\mathrm{IgE}$, and 4 of them had atopic complaints.

Serum IgG levels were elevated significantly in both 'sporadic' and 'familial' patients, even at younger ages [13]. Longitudinal IgM levels were within or just above the normal range. Longitudinal $\mathrm{IgG}$ subclass levels were studied in 34 patients (Fig. 3). The increase in serum IgG levels was not found to be due to elevated concentrations of a specific IgG subclass. Particularly in the 'familial' group, several patients demonstrated already (very) high $\mathrm{IgG}_{2}$ levels at young ages (Fig. 3). Concomitant $\mathrm{IgG}_{2}-\mathrm{IgG}_{4}$ deficiency was found in two boys both belonging to the 'sporadic' group. One was a mentally retarded child with ring chromosome 22 but no other complaints. The other boy had considerably lowered serum IgG levels. During follow-up his serum IgG and IgM levels further declined, and he was considered to be a case of late-onset hypogammaglobulinaemia [13]. In one patient 


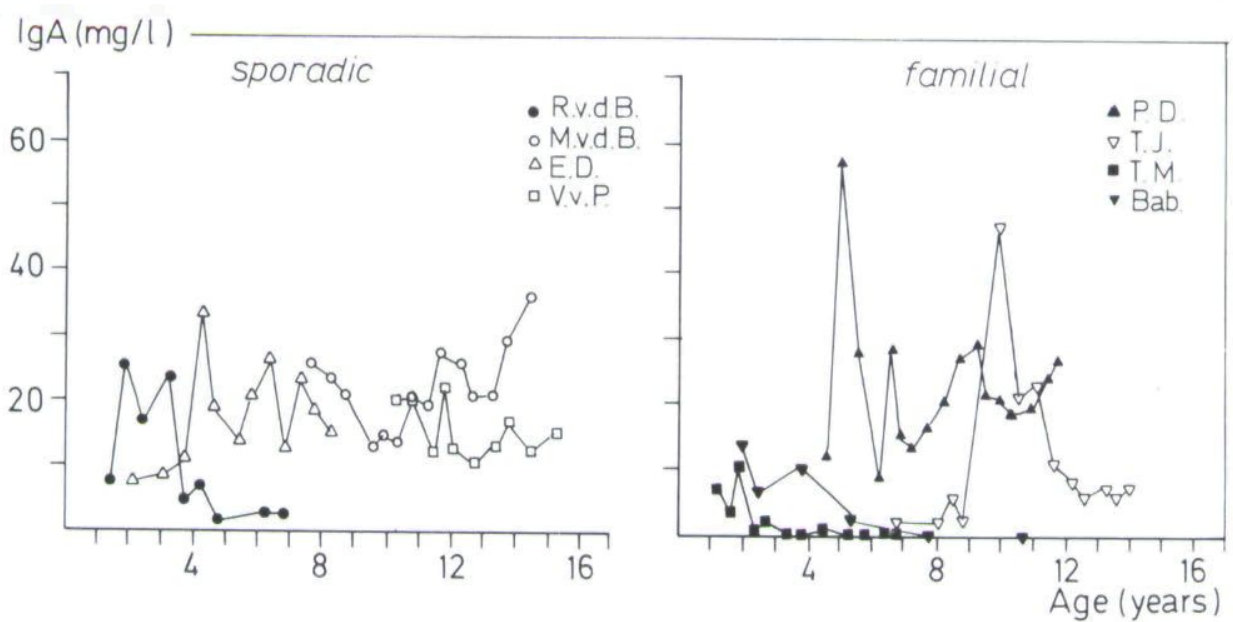

FIG. 1. Longitudinal course of serum IgA levels in 8 children with fluctuating serum IgA levels.

$\mathrm{IgG}_{2}$ levels were low at first, but increased during follow-up (Fig. 3). His $\mathrm{IgG}_{4}$ levels were very high (above $3 \mathrm{~g} / \mathrm{l}$ ). Undetectable $\mathrm{IgG}_{4}$ levels alone were noted in 5 children ( 4 'sporadic' and 1 'familial').

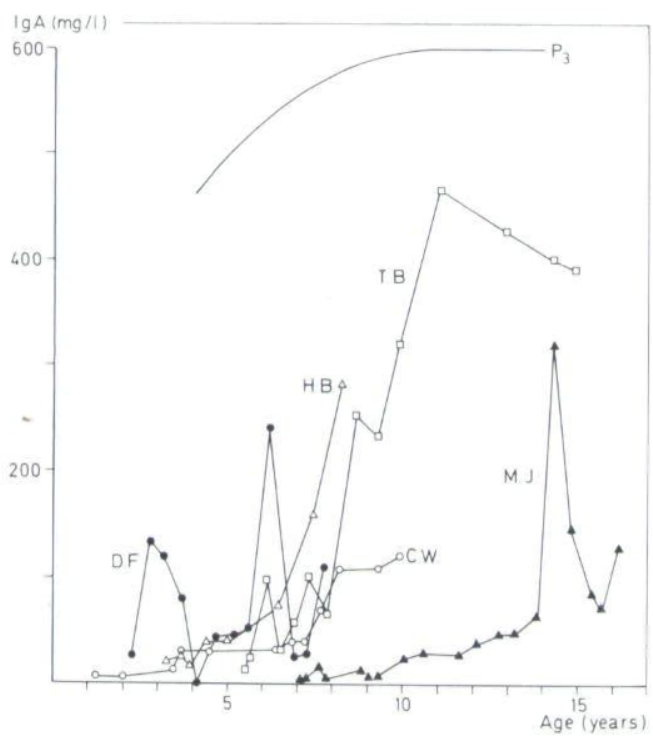

FIG. 2. Longitudinal course of serum IgA levels in 5 children who developed serum IgA levels above $50 \mathrm{mg} / 1$ during the follow-up period (patients C.W., H.B. and T.B. are 'sporadic'; D.F. and M.J. are 'familial' cases). The drawn line represents the $\mathrm{P}_{3}$ percentile for serum IgA levels of healthy Dutch school children obtained in an earlier study [15].

\section{$\operatorname{Ig} A$ in saliva}

Secretory IgA was measured once or twice in saliva of 32 children. If serum IgA levels were below $2 \mathrm{mg} / \mathrm{l}$, saliva IgA levels were also below 2 $\mathrm{mg} / \mathrm{l}$ in all patients. Saliva IgA measurements in children with longitudinal serum IgA levels above $2 \mathrm{mg} / \mathrm{l}$ are shown in Table II. In the children with serum $\mathrm{IgA}$ levels increasing above $50 \mathrm{mg} / \mathrm{l}$ (Fig. 2), IgA was also detectable in saliva (Table II).

TABLE I. Longitudinal serum IgA and IgD levels in 28 children with selective $\operatorname{IgA}$ deficiency $(8$ children were excluded because of insufficient data for $\mathrm{IgD}$ )

\begin{tabular}{|c|c|c|c|}
\hline & \multicolumn{2}{|c|}{$\operatorname{IgD}$} & \\
\hline & \multicolumn{2}{|c|}{$<1 \mathrm{IU} / \mathrm{ml}>1 \mathrm{IU} / \mathrm{ml}$} & \\
\hline \multicolumn{4}{|l|}{ Sporadic $(n=17)$} \\
\hline $\operatorname{IgA}<2 \mathrm{mg} / 1$ & 9 & 1 & \multirow[b]{2}{*}{$\begin{array}{c}P=0.007 \\
(\text { Fisher test) }\end{array}$} \\
\hline $\mathrm{IgA}>2 \mathrm{mg} / 1$ & 1 & 6 & \\
\hline \multicolumn{4}{|l|}{ Familial $(n=11)$} \\
\hline $\operatorname{IgA}<2 \mathrm{mg} / 1$ & 3 & 2 & \multirow{2}{*}{ Not significant } \\
\hline $\operatorname{IgA}>2 \mathrm{mg} / 1$ & 2 & 4 & \\
\hline
\end{tabular}

\section{DISCUSSION}

In patients without anti-IgA antibodies serum IgA was always detectable if measured by a sensitive radioimmunoassay, but most children demonstrated persistence of very low levels $(<2$ $\mathrm{mg} / \mathrm{l})$. Although still within the range set for definition of $\operatorname{IgA}$ deficiency $(<50 \mathrm{mg} / \mathrm{l})$, in some patients considerable intra-individual variance was noted. These findings are in agreement with Laschinger et al. who, in order to establish an IgA-deficient blood donor panel, still found 

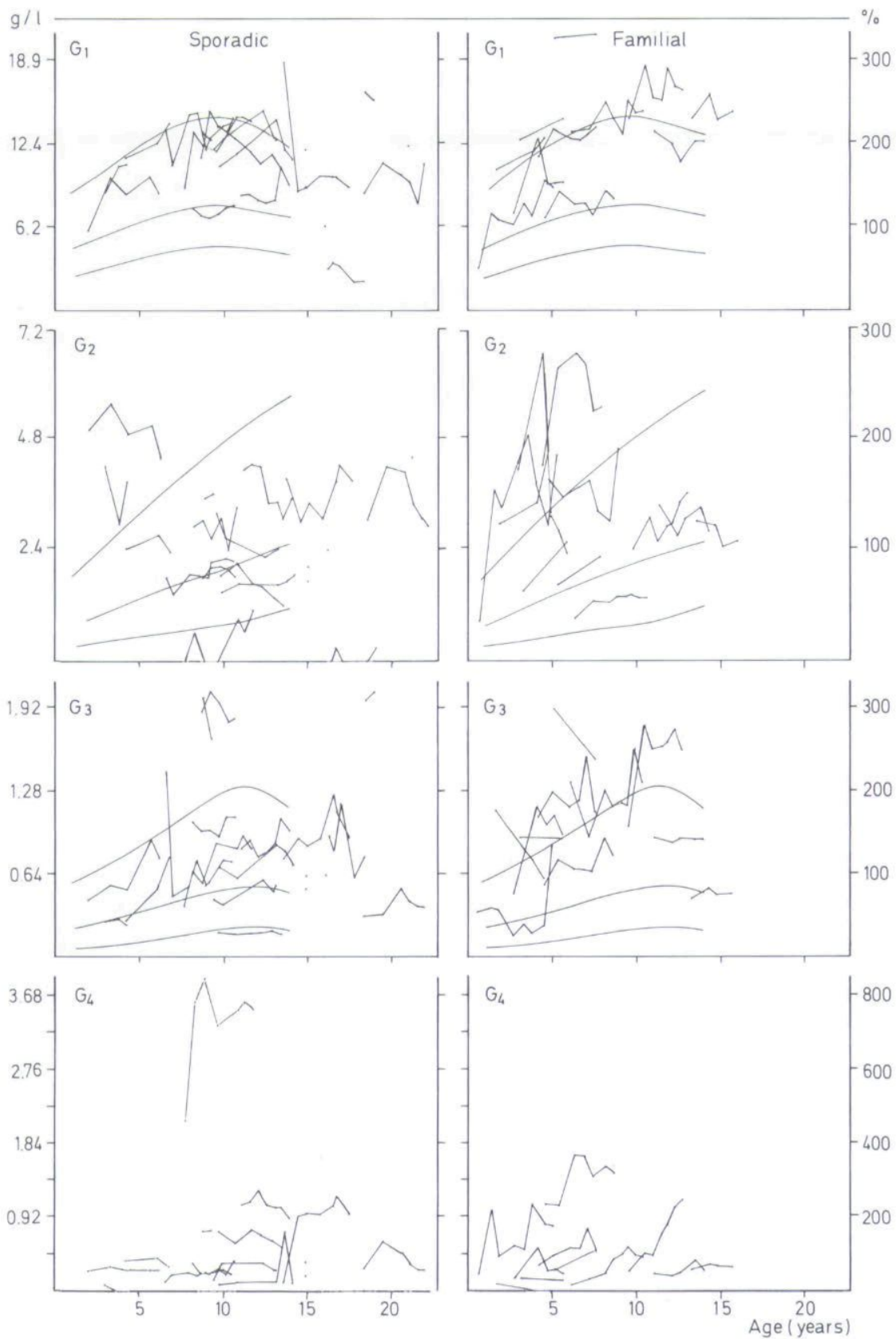

Fig. 3. Longitudinal course of $\operatorname{IgG}$ subclass levels in 32 children with selective IgA deficiency. Age-specific reference values ( 3 rd percentile curve, expected value determined using regression analysis, and 97 th percentile curve) for $\mathrm{IgG}_{1}, \mathrm{IgG}_{2}$ and $\mathrm{IgG}_{3}$ are according to Plebani et al. [17]. The right axis refers to the percentage of the reference serum.

considerable fluctuations in serum IgA concentrations even below a level of $0.5 \mathrm{mg} \operatorname{IgA} / \mathrm{I}$ [11]. The fluctuations in serum IgA levels found in some of our patients were not related with infectious episodes and there were no simulta- neous fluctuations in serums IgG or IgM levels. Studies on IgA heavy chain constant region genes (situated on chromosome 14) have revealed that there are no structural deletions in individuals with selective IgA deficiency [19]. The underlying 
TABLE II. Saliva IgA in children with longitudinal serum IgA levels above $2 \mathrm{mg} / \mathrm{l}$

\begin{tabular}{|c|c|c|c|c|c|c|}
\hline \multirow[b]{3}{*}{ Patient } & & \multicolumn{5}{|c|}{$\operatorname{IgA}$} \\
\hline & & \multicolumn{2}{|c|}{ 1st sample } & \multicolumn{3}{|c|}{ 2nd sample } \\
\hline & $\begin{array}{l}\text { Age } \\
\text { (yrs) }\end{array}$ & $\begin{array}{l}\text { Serum } \\
(\mathrm{mg} / \mathrm{l})\end{array}$ & $\begin{array}{l}\text { Saliva } \\
(\mathrm{mg} / \mathrm{l})\end{array}$ & $\begin{array}{l}\text { Age } \\
\text { (yrs) }\end{array}$ & $\begin{array}{l}\text { Serum } \\
(\mathrm{mg} / \mathrm{l})\end{array}$ & $\begin{array}{l}\text { Saliva } \\
(\mathrm{mg} / \mathrm{l})\end{array}$ \\
\hline \multicolumn{7}{|l|}{ Sporadic } \\
\hline R.vdB & 1 & 14 & $<2$ & 6 & 2.3 & $<2$ \\
\hline E.D. & 2 & 8 & 8 & 8 & 19 & 32 \\
\hline M.vdB. & 8 & 20 & $<2$ & 11 & 19 & 11.1 \\
\hline V.P. & 10 & 20 & $<2$ & - & - & - \\
\hline C.W. & 4 & 31 & $<2$ & 9 & 112 & 39 \\
\hline H.B. & 4 & 23 & 6.6 & & & \\
\hline T.B. & 6 & 32 & $<2$ & 14 & 380 & 139 \\
\hline \multicolumn{7}{|l|}{ Familial* } \\
\hline T.M. & 1 & 7.6 & $<2$ & - & - & - \\
\hline P.D. & 4 & 11.7 & 4.2 & 9 & 21.2 & 41.1 \\
\hline T.J. & 7 & 2.2 & $<2$ & 13 & 6.9 & 3.5 \\
\hline D.F. & 5 & 45.1 & 3.7 & - & - & - \\
\hline M.J. & 7 & 7.0 & $<2$ & 15 & 75 & 86 \\
\hline
\end{tabular}

* Patient Bab. (Fig. 1) was not tested for saliva IgA. -, 2nd sample not available.

cause of IgA deficiency generally is considered to be a disturbance in the regulation of B-cell differentiation to IgA-secreting plasma cells [ 20 22]. Supposing that these regulatory disturbances are not constant in all patients, this could explain why in some patients fluctuating IgA levels can be found.

Five children developed serum IgA levels above $50 \mathrm{mg} / \mathrm{l}$ and $\mathrm{IgA}$ was also detectable in saliva. During the available follow-up period none of them attained the lower range of agespecific reference values for serum IgA. However, if serum IgA levels continue to rise, perhaps these patients will represent cases of transient IgA deficiency as reported previously $[4,12]$. It should be noted that in our study maturation of the $\operatorname{IgA}$ system still occurred at relatively advanced ages. This is in contrast with results of Plebani et al. who found that $\operatorname{IgA}$ deficiency in children with IgA levels below $50 \mathrm{mg} / \mathrm{l}$ is generally persistent [23].

In agreement with the elevation of longitudinal IgG levels in our patients [13], longitudinal IgG subclass levels (including $\mathrm{IgG}_{2}$ ) in most of our patients, suffering from only relatively mild infections, were generally found to be rather high. Elevated IgG subclass levels in selective $\operatorname{IgA}$ deficiency have been described by Klemola [8], but most of these patients were suffering from active diseases (juvenile chronic arthritis and coeliac disease). One of our patients developed late on-set hypogammaglobulinaemia. Recently a common susceptibility gene located in the MHC class III region on chromosome 6 has been implicated for both selective IgA deficiency and common variable immunodeficiency, suggesting that these are related disorders [22, 24].

In the 'sporadic' group but not in the 'familial' group, a statistically significant association between $\operatorname{IgD}$ deficiency and serum IgA levels below $2 \mathrm{mg} / \mathrm{l}$, and between detectable serum $\mathrm{IgD}$ and serum IgA levels above $2 \mathrm{mg} / \mathrm{l}$, was found. Two children with serum IgA levels above 50 $\mathrm{mg} / \mathrm{l}$, who thus far did not fully mature to normal $\operatorname{IgA}$ levels, developed IgD deficiency in the same period. Concomitant $\mathrm{IgD}$ deficiency in individuals with $\operatorname{IgA}$ deficiency has been reported previously $[7,10]$. In our patients no relation could be established between clinical manifestations and the height of serum IgD levels. The role of $\mathrm{IgD}$ in the regulation of the immune response is not clear as yet. In a sequence of studies by Coico and co-workers an immunoaugmenting effect of $\mathrm{IgD}$ in both primary and secondary responses has been described in the murine system [25]. Injection of myeloma-derived $\mathrm{IgD}$ caused an increase in the numbers of $\mathrm{IgA}$ and $\mathrm{IgG}_{2}$-producing spleen cells. It was shown 
that the immuno-augmenting effect of $\mathrm{IgD}$ was $\mathrm{T}$ cell-dependent [25]. T cells with receptors for IgD (T-delta cells) involved in the humoral immune response have also been demonstrated in humans [26]. The relation between longitudinal $\operatorname{IgA}$ and IgD levels in our patients could suggest an immunoregulatory role for IgD in the development of a mature IgA system. The difference observed in $\operatorname{IgA}$ and $\mathrm{IgD}$ levels between both groups support would then support a difference in the mechanism causing IgA deficiency in 'sporadic' and 'familial' patients. However, another explanation for the relation observed between $\operatorname{IgA}$ and $\operatorname{IgD}$ levels to be considered would be that both are influenced by a common mechanism regulating $\mathrm{B}$-cell differentiation.

In conclusion, in a previous report we found that there were no obvious differences in clinical manifestations between the 'sporadic' and 'familial' groups [13]. In the present study, apart from the statistically significant association observed between longitudinal serum IgA and IgD levels in the 'sporadic' group, no differences could be established in longitudinal immunoglobulin levels between 'sporadic' and 'familial' cases of selective IgA deficiency.

\section{REFERENCES}

1 Ammann AJ, Hong R. Selective IgA deficiency: presentation of 30 cases and a review of the literature. Medicine 1971;50:223-36.

2 Hong R, Ammann A. Disorders of the IgA system. In: Stiehm RT, ed. Immunologic Disorders of Infants and Children, Philadelphia: Saunders, 1989:329 42 .

3 Klemola T. Deficiency of immunoglobulin A. Ann Clin Res 1987;19:248 57.

4 Buckley RH. Clinical and immunologic features of selective IgA deficiency. Birth Defects 1975;11:134 42.

5 Oen K, Petty RE, Schroeder ML. Immunoglobulin A deficiency: genetic studies. Tissue Antigens 1982;19:174-82.

6 Oxelius VA, Laurell A, Lindquist B, Golebiowska H, Axelsson U, Björkander J, Hanson LA. IgG subclasses in selective IgA deficiency. Importance of IgG2-IgA deficiency. N Engl J Med 1981;304:1476 7.

7 Out TA, Munster PJJ van, Graeff PA de, Thé TH, Vossen JM, Zegers BJM. Immunological investigations in individuals with selective IgA deficiency. Clin Exp Immunol 1986;64:510-17.

8 Klemola T, Seppala I, Savilahti E. Serum IgG subclass levels in paediatric clinic patients with variable degrees of $\mathrm{IgA}$ deficiency. J Clin Lab Immunol 1988;25:29-34.
9 Plebani A, Mira E, Mevio E, Monafo V, Notarangelo LD, Avanzini A, Ugazio AG. IgM and IgD concentrations in the serum and secretions of children with selective IgA deficiency. Clin Exp Immunol 1983:53:689-96.

10 Buckley RH, Fiscus SA. Serum $\operatorname{IgD}$ and $\mathrm{IgE}$ concentrations in immunodeficiency diseases. J Clin Invest 1975;55:157-65.

11 Laschinger C, Gauthier D, Valet JP, Naylor DH. Fluctuating levels of serum $\operatorname{IgA}$ in individuals with selective IgA deficiency. Vox Sang 1984;47:60-7.

12 Blum PM, Hong R, Stiehm R. Spontaneous recovery of selective IgA deficiency. Additional case reports and a review. Clin Pediatr 1982;21:77-80.

13 Laat PCJ de, Weemaes CMR, Gonera R, Munster PJJ van, Bakkeren JAJM, Stoelinga GBA. Clinical manifestations in selective IgA deficiency in childhood: a follow-up report. Acta Paediatr Scand 1991;80:798-804.

14 Munster PJJ van, Stoelinga GBA. Over de isolering en bepaling van immuunglobuline A ( $\operatorname{IgA})$. Maandschr Kindergeneesk 1965;33:428-33.

15 Weemaes CMR, Hendrickx GFM, Hof MA van't, Munster PJJ van, Stoelinga GBA. Age changes in serum immunogloublins. In: Prahl-Anderson B, Kowalski CJ, Heydendaal P, ed. A Mixed Longitudinal Interdisciplinary Study of Growth and Development. New York: Academic Press, 1979:465-89.

16 Munster PJJ van, Nadorp JHSM, Schuurman HJ. Human antibodies to immunoglobulin A (IgA). A radioimmunological method for differentiation between anti-IgA antibodies and $\mathrm{IgA}$ in the serum of IgA deficient individuals. J Immunol Methods 1978;22:233-45.

17 Plebani A, Ugazio AG, Avanzini MA, Massini P, Zonta L, Monafo V, Burgio GR. Serum IgG subclass concentrations in healthy subjects at different age: age normal percentile charts. Eur J Pediatr 1989;149:164-7.

18 Kjellmann NIM. Predictive value of high IgE levels in children. Acta Paediatr Scand 1976;65:465-71.

19 Hammarstrom L, Carlsson B, Smith CI, Wallin J, Wislander L. Detection of IgA heavy chain constant region genes in $\operatorname{IgA}$ deficient donors: evidence against gene deletions. Clin Exp Immunol 1985;60:661-4.

20 McGhee JR, Mestecky J, Elson CO, Kiyono H. Regulation of $\operatorname{IgA}$ synthesis and immune response by $\mathrm{T}$ cells and interleukins. J Clin Immunol 1989:9:175-99.

21 Huston DP, Kavanaugh AF, Rohane PW, Huston MM. Immunoglobulin deficiency syndromes and therapy. J Allergy Clin Immunol 1991;87:1-17.

22 French MAH, Dawkins RL. Central MHC genes, IgA deficiency and auto-immune disease. Immunol Today 1990;11:271-4.

23 Plebani A, Monafo V, Ugazio AG, Burgio GR. Clinical heterogeneity and reversibility of selective immunoglobulin A deficiency in 80 children. Lancet 1986;i:829-31.

24 Schaffer FM, Palermos J, Zhu ZB, Barger BO, Cooper MD, Volanakis JE. Individuals with $\operatorname{IgA}$ deficiency and common variable immunodeficiency 
share polymorphisms of major histocompatibility complex class III genes. Proc Natl Acad Sci USA 1989:86:8015-19.

25 Coico RF, Siskind GW, Thorbecke GJ. Role of IgD and T-delta cells in the regulation of the humoral immune response. Immunol Rev 1988;105:45-67.

26 Coico RF, Tamma SL, Bessler M, Wei CF, Thor- becke GJ. IgD-receptor-positive human T cells. I. Modulation of receptor expression by oligomeric IgD and lymphokines. J Immunol 1990;145:355661 .

Received 21 October 1991

Accepted in revised form 7 February 1992 
This document is a scanned copy of a printed document. No warranty is given about the accuracy of the copy. Users should refer to the original published version of the material. 